\title{
GMR
}

\section{Multivariate diallel analysis allows multiple gains in segregating populations for agronomic traits in Jatropha}

P.E. Teodoro ${ }^{1}$, E.V. Rodrigues ${ }^{2}$, L.A. Peixoto ${ }^{1}$, L.A. Silva ${ }^{1}$, B.G. Laviola ${ }^{2}$ and L.L. Bhering ${ }^{1}$

${ }^{1}$ Laboratório de Biometria, Departamento de Biologia Geral, Universidade Federal de Viçosa, Viçosa, MG, Brasil

${ }^{2}$ Embrapa Agroenergia, Brasília, DF, Brasil

Corresponding author: L.L. Bhering

E-mail: leonardo.bhering@ufv.br

Genet. Mol. Res. 16 (1): gmr16019545

Received November 21, 2016

Accepted February 17, 2017

Published March 22, 2017

DOI http://dx.doi.org/10.4238/gmr16019545

Copyright $(2017$ The Authors. This is an open-access article distributed under the terms of the Creative Commons Attribution ShareAlike (CC BY-SA) 4.0 License.

\begin{abstract}
Jatropha is research target worldwide aimed at largescale oil production for biodiesel and bio-kerosene. Its production potential is among 1200 and $1500 \mathrm{~kg} / \mathrm{ha}$ of oil after the 4th year. This study aimed to estimate combining ability of Jatropha genotypes by multivariate diallel analysis to select parents and crosses that allow gains in important agronomic traits. We performed crosses in diallel complete genetic design ( $3 \times 3)$ arranged in blocks with five replications and three plants per plot. The following traits were evaluated: plant height, stem diameter, canopy projection between rows, canopy projection on the line, number of branches, mass of hundred grains, and grain yield. Data were submitted to univariate and multivariate diallel analysis. Genotypes 107 and 190 can be used in crosses for establishing a base population of Jatropha, since it has favorable alleles for increasing the mass of hundred grains and grain yield and reducing the plant height. The cross $190 \times 107$ is the
\end{abstract}

Genetics and Molecular Research 16 (1): gmr16019545 
most promising to perform the selection of superior genotypes for the simultaneous breeding of these traits.

Key words: Jatropha curcas L.; Multivariate statistics; Parental selection; Hybrid selection; Selection index; Genetic breeding

\section{INTRODUCTION}

Jatropha curcas L. is an oleaginous species with great potential for biofuel production (Laviola et al., 2013) because it does not compete against annual crops used as a source of human and animal food. In Brazil, this species is in domestication phase (Bahadur et al., 2013; Carels et al., 2013), being necessary more studies on genetic breeding to increase the productive potential of the crop, given that currently there is no commercial cultivar in Brazil (Teodoro et al., 2016a).

Thus, to install a genetic breeding program of Jatropha in Brazil numerous studies have been conducted in recent years, such as studies on genetic diversity (Rosado et al., 2010; Bhering et al., 2015), estimates of genetic parameters (Laviola et al., 2012; Teodoro et al., 2016d) and gains with selection (Bhering et al., 2013; Peixoto et al., 2016), repeatibility (Laviola et al., 2013, Teodoro et al., 2016b), and path analysis (Teodoro et al., 2016c). However, for the formation of base populations for practicing the selection, diallel is the main genetic design used (Cruz et al., 2012).

In the literature, there are different methods for diallel analysis, among which Griffing (1956) is widely used because it allows estimating useful parameters in selecting parents and promising hybrid combinations. This method allows estimating the effects of general combining ability (GCA), which is dependent on the concentration of predominantly additive genes; specific combining ability (SCA), which is a result of the concentration of non-additive effect genes, reciprocal effects related to maternal inheritance, and extrachromosomal effects.

However, the traits measured are individually analyzed by univariate diallel analysis, which causes difficulties in the parent recommendation and superior hybrid combination, since most breeding programs aimed to obtain gain in multiple traits simultaneously. An alternative is the use of multivariate diallelic analysis, which allows analyzing multiple traits, facilitating the selection and discrimination of the most promising populations.

Therefore, this research was conducted in order to estimate the GCA and SCA using multivariate diallel analysis to recommend the most promising parents and crosses to reduce size and increase yield in Jatropha.

\section{MATERIAL AND METHODS}

\section{Experimental area}

Trial was conducted at the experimental area of Embrapa Cerrado in 2010-2015, in the municipality of Planaltina, Federal District. The municipality is located at $15^{\circ} 35^{\prime} 30^{\prime \prime} \mathrm{S}$, $47^{\circ} 42^{\prime} 30^{\prime \prime} \mathrm{W}$, at $1007 \mathrm{~m}$ of altitude. Climate is tropical with dry winter and rainy summer (Aw), according to Köppen's classification, with average annual temperature of $21^{\circ} \mathrm{C}$, relative humidity of $68 \%$ and average rainfall of $1100 \mathrm{~mm}$ per year. Management practices were based on Dias et al. (2007), with adaptations according to the search results with Jatropha in Brazil and in the world (Durães et al., 2012; Bahadur et al., 2013; Carels et al., 2013; Resende et al., 2013).

Genetics and Molecular Research 16 (1): gmr16019545 


\section{Experimental design and traits evaluated}

Crosses were performed in complete diallel genetic design, with three self-pollination and six hybridizations. Experimental design was randomized blocks, with five replications, three plants per plot and spacing $4 \times 2 \mathrm{~m}$. For performing the crosses, we used three genotypes selected in the germplasm bank with the following features: short size (CNPAE-107), high grain yield (CNPAE-190), and resistance to powdery mildew (CNPAE-259).

The traits evaluated were: plant height $(\mathrm{PH}, \mathrm{m})$, stem diameter $(\mathrm{SD}, \mathrm{mm})$, canopy projection between rows (CPR, $\mathrm{m})$, canopy projection on the line (CPL, $\mathrm{m})$, number of branches (NB), mass of hundred grains (MHG), and grain yield (YIE, g/planta). The traits $\mathrm{PH}$, $\mathrm{CPR}, \mathrm{CPL}$, and NB were assessed in the third year; SD was assessed in the first year; MHG was quantified in the fourth year; YIE was assessed in the fifth year.

\section{Statistical analysis}

Initially, univariate diallel analysis was performed for each trait according to model 1 proposed by Griffing (1956). Multivariate diallel analysis was carried out according to the procedures performed by Ledo et al. (2003). Equality hypothesis of the genetic effects of multivariate diallel analysis was assessed with the Wilks test (Harris, 1975). Subsequently, we performed principal component analysis and selection index established by Pešek and Baker (1969), with the genotypic aggregate obtained according to the methodology described by Cruz et al. (2012). Pearson correlation was estimated between the first two principal components and the mean agronomic traits. Finally, the effects of GCA and SCA for the scores from each principal component and genotypic aggregate were estimated. All statistical analyzes were performed using Genes software (Cruz, 2013).

\section{RESULTS AND DISCUSSION}

Univariate diallel analysis showed a significant effect for the effect of genotypes (Table 1), demonstrating ability to select superior genotypes in the segregating populations with advances in generations. We found that the effects of dominance $\left(\Phi_{\mathrm{sc}}\right)$ were higher in the genetic control for all traits, which indicates the existence of differences in progenitor's genic composition. According to Cruz et al. (2012), when larger estimates for $\Phi_{\mathrm{sc}}$ are obtained in relation to others, the parents are different for most of the loci in dominance and heterotic manifestations exhibited by these crosses can be credited to genetic complementation between the loci that control the traits evaluated. These results were expected because Rosado et al. (2010) observed genetic diversity at molecular level among the parents used in this diallel, which were divided into different groups.

Despite the effect of dominance have greater importance on the studied features, it is important to mention the significance of the effects of GCA and reciprocal for all traits except GCA for the CPL. These results indicate that in addition to the effects of dominance, additive genetic effects and maternal and/or extrachromosomal effects should be considered in breeding program aimed at improving traits assessed in this study. Similar results were reported by Biabani et al. (2012) and Santana et al. (2013), who by using diallel crosses in Jatropha observed a significant effect on GCA and SCA.

For easier selection of superior parents and promising crosses based on traits of

Genetics and Molecular Research 16 (1): gmr16019545 
interest, we performed diallel multivariate analysis (Table 2) by extension of the model 1 established by Griffing (1956). This analysis was significant by the Wilk test, indicating that the parents and the hybrid combinations have complementary alleles and the traits can be considered together in diallel analysis (Ledo et al., 2003; Silva et al., 2008; Benin et al., 2009).

Table 1. Univariate diallel analysis and quadratic components $(\Phi)$ for the traits plant height $(\mathrm{PH})$, stem diameter (SD), canopy projection between rows (CPR), canopy projection on the line (CPL), number of branches (NB), mass of hundred grains (MHG), and grain yield (YIE) evaluated in nine Jatropha genotypes.

\begin{tabular}{l|c|c|c|c|c|c|c|c}
\hline SV & d.f. & PH & SD & CPR & CPL & NB & MHG & YIE \\
\hline Genotypes & 8 & $0.55^{*}$ & $147.11^{*}$ & $0.70^{*}$ & $0.637^{*}$ & $176.32^{*}$ & $462.84^{*}$ & $1549525.65^{*}$ \\
\hline GCA & 2 & $0.40^{*}$ & $373.17^{*}$ & $0.04^{*}$ & $0.003^{\text {ns }}$ & $117.20^{*}$ & $756.98^{*}$ & $2193597.26^{*}$ \\
\hline SCA & 3 & $0.94^{*}$ & $90.03^{*}$ & $1.23^{*}$ & $0.799^{*}$ & $210.57^{*}$ & $546.34^{*}$ & $2154437.05^{*}$ \\
\hline Reciprocal & 3 & $0.25^{*}$ & $53.49^{*}$ & $0.61^{*}$ & $0.898^{*}$ & $181.49^{*}$ & $183.26^{*}$ & $515233.17^{*}$ \\
\hline Error & 32 & 0.02 & 9.39 & 0.03 & 0.039 & 19.03 & 16.73 & 88121.92 \\
\hline$\Phi_{\mathrm{gc}}$ & - & 0.01 & 12.13 & 0.00 & 0.0 & 3.27 & 24.67 & 70182.51 \\
\hline$\Phi_{\mathrm{sc}}$ & - & 0.19 & 16.13 & 0.24 & 0.15 & 38.31 & 105.92 & 413263.02 \\
\hline$\Phi_{\mathrm{rc}}$ & - & 0.02 & 4.41 & 0.06 & 0.09 & 16.25 & 16.65 & 42711.12 \\
\hline
\end{tabular}

*Significant at $5 \%$ probability by the F-test; ns: non-significant, SV: source of variation; d.f.: degrees of freedom; GCA: general combining ability; SCA: specific combining ability; $\Phi_{\mathrm{gc}}, \Phi_{\mathrm{sc}}$, and $\Phi_{\mathrm{rc}}$ : quadratic components from GCA, SCA, and reciprocal effects, respectively.

Table 2. Summary of multivariate diallel analysis in nine Jatropha genotypes.

\begin{tabular}{l|c|c|c}
\hline Sources of variation & d.f. & Matrix of SPS & Wilk test \\
\hline General combining ability (CGC) & 2 & SPS (GCA) & $<0.00$ \\
\hline Specific combining ability (SCA) & 3 & SPS (SCA) & $<0.00$ \\
\hline Reciprocal & 3 & SPS (Reciprocal) & $<0.00$ \\
\hline
\end{tabular}

SPS: sum of product square.

Analysis of the first two principal components retained $81 \%$ of the accumulated variance between the traits and, therefore, estimates of GCA and SCA were obtained on these components (Ledo et al., 2003). According to Cruz et al. (2012), for a satisfactory interpretation on the variability manifested among genotypes, it is necessary that the first two principal components have minimum estimates of $80 \%$ of total variation within the analyzed trait set.

To express graphically the Pearson correlation between the traits evaluated and the first two principal components, we used the correlation network, where green and red lines highlighted represent positive and negative correlations of high magnitude, respectively (Figure 1). We can verify the subdivision into the two groups: the first principal component (PC1) is positively associated with $\mathrm{PH}, \mathrm{CPL}$, and CPR; the second principal component (PC2) is positively related to the MHG, SD, and YIE.

Subdivision of traits into two principal groups is important because it met the group of first traits related to the size of the Jatropha genotypes, which must be reduced to ease the denser planting and mechanized harvesting. These traits are important in choosing the most appropriate spatial arrangement for planting because Jatropha can exceed $5 \mathrm{~m}$ high (Dias et al., 2007). Thus, efforts by breeding programs are focused on selecting plants with reduced size to facilitate the harvest. Teodoro et al. (2016b) observed that the MHG and SD have relation of cause and positive effect on grain yield in Jatropha, which reiterates the association of these traits with PC2. 


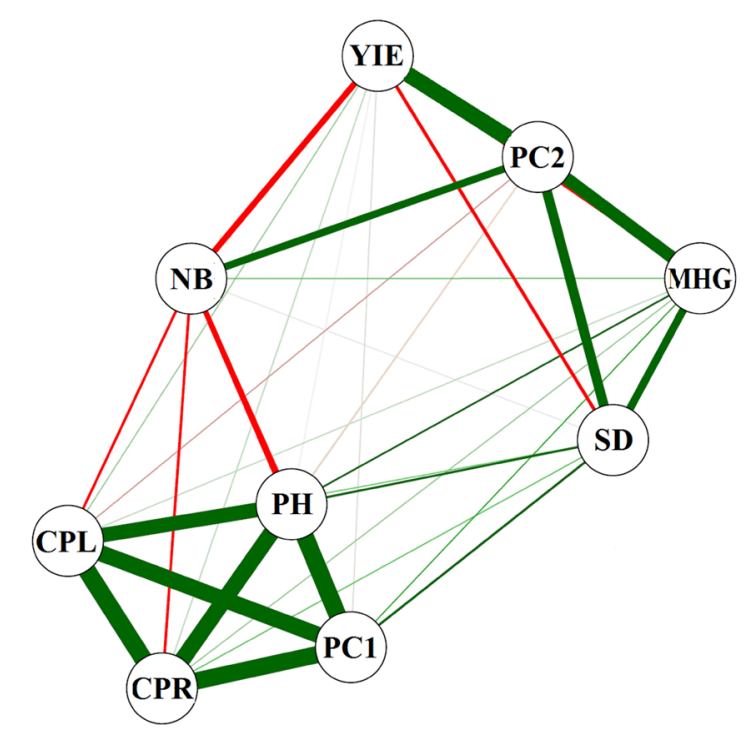

Figure 1. Network Pearson correlations between the first two principal components and agronomic traits assessed in nine Jatropha genotypes.

Pešek and Baker index (1969) was used to estimate the linear coefficients that allow positive gains $(\sim 10 \%)$ on the mass of hundred grains and grain yield and reduction $(\sim 10 \%)$ on plant height, which are the main goals of the Jatropha-breeding programs, and the other traits evaluated were considered secondary (Figure 2). After establishment of linear combinations, genotypic aggregate estimates were obtained as procedures reported by Cruz et al. (2012). It is important to mention that even the dominance effects being predominant in the genetic control for all traits, the genotypes 107 and 190 (derived from self-pollination) had genotypic aggregate estimates greater than most hybrids. These results indicate the absence of inbreeding depression for the main agronomic traits of Jatropha.

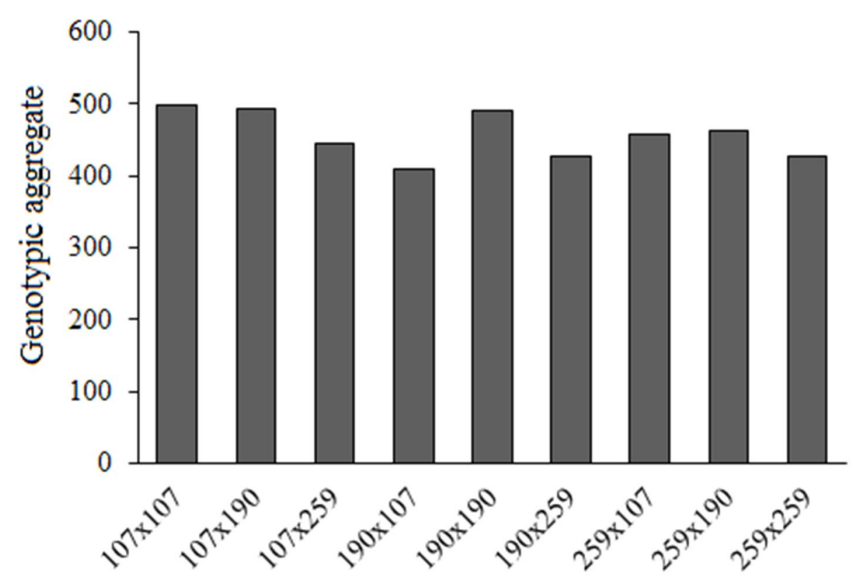

Figure 2. Genotypic aggregate obtained by the Pešek and Baker index (1969) for nine Jatropha genotypes.

Genetics and Molecular Research 16 (1): gmr16019545 
GCA for the parents, estimated from the first two principal components and the selection index is shown in Figure 3. GCA estimates provide information on the concentration of predominantly additive genes and their effects have allowed the identification of parents used to obtain populations to practice the selection (Cruz et al., 2012). We verified that the genotypes 107 and 190 showed GCA estimates negative for PC1 and positive for PC2 and genotypic aggregate obtained by Pešek and Baker index (1969). Therefore, these results indicate that these parents are the most indicated to compose the cross blocks for having alleles to increase the YIE and MHG, and to reduce the size in Jatropha, which are the main objectives of the crop-breeding programs.

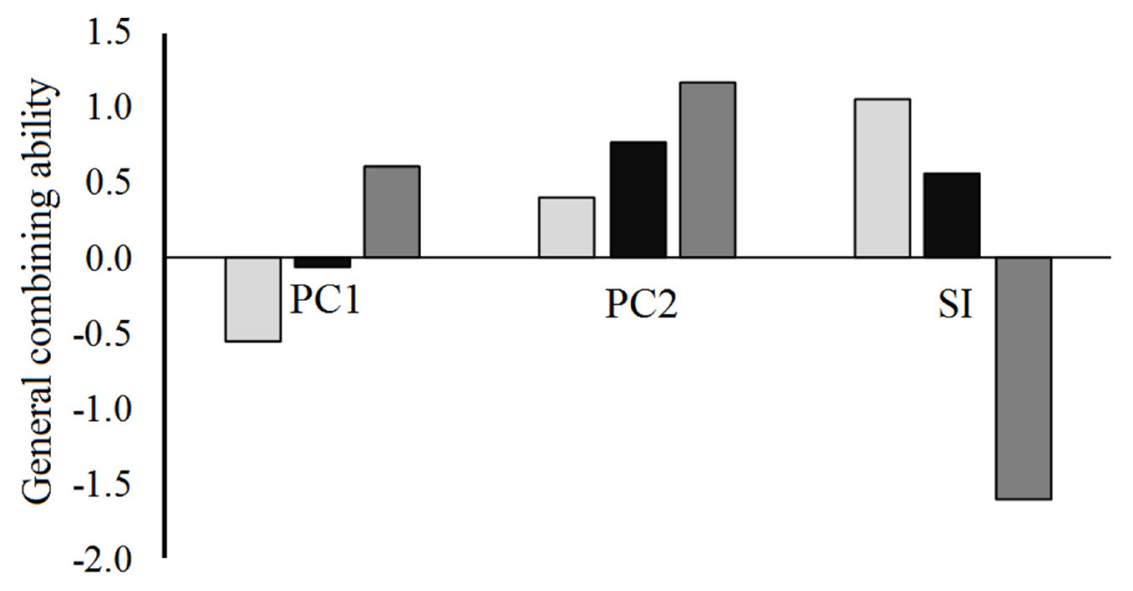

$\square 107 \square 190 \square 259$

Figure 3. General combining ability of Jatropha genotypes obtained by the first two principal components (PC1 and PC2) and genotypic aggregate obtained by the selection index (SI) of Pešek and Baker (1969).

SCA can be defined as a deviation from the performance of the cross in relation to what would be expected based on the GCA from its parents. Its effects indicate the presence of non-additive interactions resulting from allelic complementation among the parents, allowing an improvement in the estimation of the genetic gain due to heterosis exploitation using divergent crosses (Cruz et al., 2012). Thus, from Figure 4 is possible to verify that the cross $190 \times 107$ obtained SCA negative estimates for CP1 and positive for CP2 and SI, being the most promising for the selection of genotypes in the segregating generations from its self-pollination. In addition, this cross gathers the two parents that have alleles more favorable for simultaneous improvement in plant height, mass of hundred grain, and grain yield.

From the results obtained in this study, it is possible to conclude that using multivariate diallel analysis allows more detailed information on the hybrid combinations with greater chances of genetic progress for the simultaneous selection of the main traits of interest. Silva et al. (2008) and Benin et al. (2009) also reported the effectiveness of this technique in identifying the parents and superior hybrid combinations aiming at gaining multiple traits in wheat. 


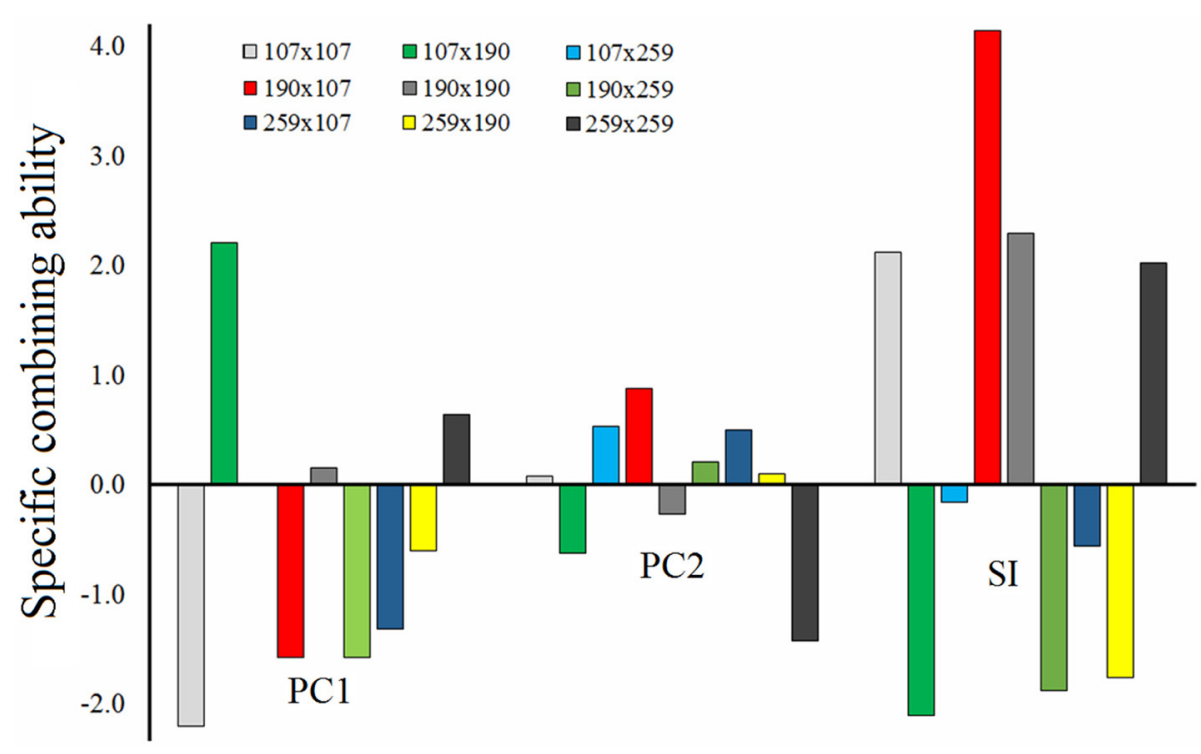

Figure 4. Specific combining ability of Jatropha genotypes obtained by the first two principal components (CP1 and CP2) and genotypic aggregate obtained by the selection index (SI) of Pešek and Baker (1969).

\section{Conflicts of interest}

The authors declare no conflict of interest.

\section{ACKNOWLEDGMENTS}

We thank CAPES (Coordenação de Aperfeicoamento de Pessoal de Ensino Superior), CNPq (Conselho Nacional de Desenvolvimento Científico e Tecnológico), FAPEMIG (Fundação de Amparo à Pesquisa de Minas Gerais), Funarbe (Fundação Arthur Bernardes), and Universidade Federal de Viçosa for financial support. We also thank the Biometric Laboratory (Universidade Federal de Viçosa, Brazil), where all analyses were performed by remote access.

\section{REFERENCES}

Bahadur B, Sujatha M and Carels N (2013). Jatropha, challenges for a new energy crop. Vol. 2: genetic improvement and biotechnology. Springer Verlag, New York.

Benin G, Silva GO, Pagliosa ES, Lemes C, et al. (2009). Capacidade de combinação em genótipos de trigo estimada por meio de análise multivariada. Pesqui. Agropecu. Bras. 44: 11451151. http://dx.doi.org/10.1590/S0100$\underline{204 X 2009000900012}$

Bhering LL, Barrera CF, Ortega D, Laviola BG, et al. (2013). Differential response of Jatropha genotypes to different selection methods indicates that combined selection is more suited than other methods for rapid improvement of the species. Ind. Crops Prod. 41: 260-265. http://dx.doi.org/10.1016/j.indcrop.2012.04.026

Bhering LL, Peixoto LL, Leite NLSF and Laviola BG (2015). Molecular analysis reveals new strategy for data collection in order to explore variability in Jatropha. Ind. Crops Prod. 74: 898-902. http://dx.doi.org/10.1016/j. indcrop.2015.06.004

Genetics and Molecular Research 16 (1): gmr16019545 
Biabani A, Rafii MY, Saleh G, Shabanimofrad M, et al. (2012). Combining ability analysis and evaluation of heterosis in Jatropha curcas (L) F,-Hybrids. Aust. J. Crop Sci. 6: 1030-1036.

Carels N, Sujatha M and Bahadur B (2013). Jatropha, Challenges for a New Energy Crop: Vol. 1: farming, economics and biofuel. Springer Verlag, New York.

Cruz CD (2013). GENES - a software package for analysis in experimental statistics and quantitative genetics. Acta Sci. Agron. 35: 271-276. http://dx.doi.org/10.4025/actasciagron.v35i3.21251

Cruz CD, Regazzi AJ and Carneiro PCS (2012). Modelos Biométricos Aplicados ao Melhoramento Genético. 3rd ed. Editora UFV, Viçosa.

Dias LAS, Leme LP, Laviola BG, Pallini Filho A, et al. (2007). Cultivo de pinhão manso (Jatropha curcas). Universidade Federal de Viçosa, Viçosa.

Durães FOM, Laviola BG and Alves AA (2012). Potential and challenges in making physic nut (Jatropha curcas L.) a viable biofuel crop: the Brazilian perspective. Plant Sci. Rev. 2011: 179.

Griffing B (1956). Concept of general and specific ability in relation to diallel crossing systems. Aust. J. Biol. Sci. 9: $462-$ 493. http://dx.doi.org/10.1071/BI9560463

Harris RJ (1975). A primer of multivariate statistics. New York: Academic press.

Laviola BG, Alves AA and Gurgel Fd D (2012). Estimates of genetic parameters for physic nut traits based in the germplasm two years evaluation. Cienc. Rural 42: 429-435. http://dx.doi.org/10.1590/S0103-84782012000300008

Laviola BG, Oliveira AMCE, Bhering LL, Alonso AA, et al. (2013). Estimates of repeatability coefficients and selection gains in Jatropha indicate that higher cumulative genetic gains can be obtained by relaxing the degree of certainty in predicting the best families. Ind. Crops Prod. 51: 70-76. http://dx.doi.org/10.1016/j.indcrop.2013.08.016

Ledo CAS, Ferreira DF and Ramalho MAP (2003). Análise de variância multivariada para os cruzamentos dialélicos. Cienc. Agrotec. 27: 1214-1221. http://dx.doi.org/10.1590/S1413-70542003000600002

Peixoto LA, Laviola BG, Bhering LL, Mendonça S, et al. (2016). Oil content increase and toxicity reduction in jatropha seeds through family selection. Ind. Crops Prod. 80: 70-76. http://dx.doi.org/10.1016/j.indcrop.2015.10.034

Pešek J and Baker RJ (1969). Desired improvement in relation to selection indices. Can. J. Plant Sci. 49: 803-804 http:// dx.doi.org/10.4141/cjps69-137.

Resende JCF, Londe LN and Neves WS (2013). Pinhão-manso. Epamig, Nova Porteirinha.

Rosado TB, Laviola BG, Faria DA, Pappas MR, et al. (2010). Molecular Markers Reveal Limited Genetic Diversity in a Large Germplasm Collection of the Biofuel Crop Jatropha curcas L. in Brazil. Crop Sci. 50: 2372-2382. http:// dx.doi.org/10.2135/cropsci2010.02.0112

Santana UA, Carvalho JLS, Blank AF and Silva-Mann R (2013). Capacidade combinatória e parâmetros genéticos de genótipos de pinhão-manso quanto a caracteres morfoagronômicos. Pesqui. Agropecu. Bras. 48: 1449-1456. http:// dx.doi.org/10.1590/S0100-204X2013001100005

Silva GO, Pereira AS, Souza VQ, Carvalho FIF, et al. (2008). Capacidade de combinação multivariada para caracteres de tubérculo em gerações iniciais de seleção em batata. Cienc. Rural 38: 321-325. http://dx.doi.org/10.1590/S0103$\underline{84782008000200004}$

Teodoro PE, Bhering LL, Costa RH, Rocha RB, et al. (2016a). Mixed models for selection of Jatropha progenies with high adaptability and yield stability in Brazilian regions. Genet. Mol. Res. 15: gmr.15038824.

Teodoro PE, Costa RH, Rocha RB and Laviola BG (2016b). Contribuição de caracteres agronômicos para a produtividade de grãos em pinhão-manso. Bragantia 75: 51-56. http://dx.doi.org/10.1590/1678-4499.314

Teodoro PE, Costa RH, Rocha RB and Laviola BG (2016c). Número mínimo de medições para a avaliação acurada de características agronômicas de pinhão-manso. Pesqui. Agropecu. Bras. 51: 112-119. http://dx.doi.org/10.1590/ $\underline{\text { S0100-204X2016000200003 }}$

Teodoro PE, Laviola BG, Martins LD, Amaral JFT, et al. (2016d). Mixed models identify physic nut genotypes adapted to environments with different phosphorus availability. Genet. Mol. Res. 15: gmr.15038429.

Genetics and Molecular Research 16 (1): gmr16019545 